INSTITUTE OF FORESTRY • BELGRADE

INSTITUT ZA ŠUMARSTVO • BEOGRAD

SUSTAINABLE FORESTRY

COLLECTION 73-74, 2016

ODRŽIVO ŠUMARSTVO

ZBORNIK RADOVA 73-74, 2016

UDK 630 $* 443.3: 582.632 .2=111$

Original scientific paper

\title{
EFFECTS OF Coniophora puteana (Schumach.) P. Karst. FUNGUS ON THE DECOMPOSITION OF SESSILE OAK WOOD
}

\author{
Miroslava MARKOVIĆ, Snežana RAJKOVIĆ ${ }^{1}$
}

\begin{abstract}
The paper examines the effects of a brown rot agent - Coniophora puteana (Schumach.) P. Karst on the mass loss and compression strength of sessile oak ( $Q$. petraea agg) wood. The wood mass loss of $Q$. petraea agg., caused by $C$. puteana amounted to 1.5, 2.12 and 2.23 after 2, 4 and 6 months respectively. The obtained values indicate that the biggest mass loss of wood occurred in the first two months. Compression strength also decreased under the influence of $C$. puteana. In comparison to its initial value (100\%), it amounted to 92.13, 90.72 and 76.25 after 2, 4 and 6 months. The analysis of the correlation between the sessile oak mass loss - $G_{m}$ and compression strength decrease - $\sigma_{p}$ (dependent variables) and the incubation time (T-independent variable) revealed a strong correlation between the variables and the following regression equations were obtained:
\end{abstract}

$$
\begin{gathered}
G_{m}=0.0638492+0.954107 \times \sqrt{\mathrm{T}} \\
\sigma_{p}=96.328-2.666 \times \mathrm{T}
\end{gathered}
$$

Key words: Coniophora puteana, mass loss, compression strength

\section{DEJSTVO GLJIVE Coniophora puteana (Schumach.) P. Karst. NA RAZLAGANJE DRVETA HRASTA KITNJAKA}

\footnotetext{
${ }^{1}$ Autor za kontakt: Dr Miroslava Marković, naučni saradnik, Institut za šumarstvo, Beograd, tel. +381691999116, Email: mira013@gmail.com

Dr Snežana Rajković, naučni savetnik, Institut za šumarstvo, Beograd
}

Acknowledgment: The study was carried out within the Project TR 31070 "The development of technological procedures in forestry with a view to an optimum forest realization", financed by the Ministry of Education, Science and Technological Development of the Republic of Serbia (20102016). 
Izvod: Ispitan je uticaj prouzrokovača mrke prizmatične truleži Coniophora puteana (Schumach.) P. Karst., na gubitak mase i smanjenje pritisne čvrstoće kitnjaka (Quercus petraea agg.). Gubitak mase drveta Q. petraea agg., pod dejstvom gljive C. puteana, posle 2, 4 i 6 meseci inkubacije iznosio je 1.5, 2.12 i 2.23, što znači da je najveći gubitak mase drveta nastupa u prva dva meseca. Utvrđeno je da se pritisna čvrstoća drveta $Q$. petraea agg. pod dejstvom gljive $C$. puteana posle 2, 4 i 6 meseci smanjila u odnosu na početnu $(100 \%)$ i iznosila 92.13, 90.72 i 76.25. Korelacionom analizom gubitka mase $-G_{m} i$ smanjenja pritisne čvrstoće drveta kitnjaka - $\sigma_{p}$ (zavisno promenljive) u odnosu na vreme dejstva gljive C. puteana ( $T$ - nezavisno promenljiva), konstatovana je jaka veza između promenljivih i dobijene su regresione jednačine :

$$
\begin{gathered}
G_{m}=0,0638492+0,954107 \times \sqrt{\mathrm{T}} \\
\sigma_{p}=96,328-2,666 \times T
\end{gathered}
$$

Ključne reči: Coniophora puteana, gubitak mase, pritisna čvrstoća

\section{INTRODUCTION}

During their development, wood-decaying fungi feed on the basic constituents of wood and thus change not only its chemical composition but also the entire inner structure, which results in the change i.e. reduction of its mechanical, physical, aesthetic and other properties (Uščuplić, 1996). If we want to determine how wood-decaying fungi affect wood properties, it is necessary to analyze their nutrition requirements and the changes that their activity produces in the structure of wood. Brown rot agents are more destructive to wood than white rot agents (Muntañola-Cvetković, 1987) due to their intensive degradation of cellulose, which is one of the most important constituents of wood cell walls, Petrović (1980). This process, depending on the conditions and the time of fungal activity, degrades cell walls and reduces or completely destroys wood properties, Rypáček (1957). The growth of mycelia simultaneously gives rise to the decay process, leading wood mass to the state in which the natural properties (color, structure, composition) are changed under the influence of microorganisms which use enzymes from hypha cells to enforce this transformation.

As a host tree, oak is colonized by a large number of microorganisms, Čeremesinov et al., (1970) and the effects of the fungi, particularly of the species that attack the heartwood as the most valuable portion of a tree, is a topic of special importance in the research of oakwood destructors. Oak is one of the most significant tree species in our country and thus 'the preservation and sustainability of its wood and the products made of it are directly related to the preservation of its mechanical, physical, chemical, aesthetic and other properties. Therefore, monitoring of the changes in the above-stated properties under the influence of fungi is imposed as logical and necessary' (Mirić and Popović, 1993). The importance of oak wood, primarily of its heartwood, for the industry in general and the significant role of $C$. puteana in its decomposition and degradation were the key factors in determining the direction of the research into the reduction of physical and mechanical properties of oak heartwood under the influence of the fungus. The results of these investigations will provide a deeper insight into the 
course as well as the causes and effects of $C$. puteana activity on the most important properties that characterize oak wood in terms of its usability and ease of processing as one of our noblest broadleaves.

\section{MATERIAL AND METHODS}

The test samples were taken from a healthy sessile oak tree, aged 115 years, $18.9 \mathrm{~m}$ in height and $34 \mathrm{~cm}$ in diameter at breast height. The tree was felled in Quercetum montanum (Čer. et Jov., 1953, according to To mić,Z.1992) association at a southern aspect and an altitude of $550 \mathrm{~m}$. A $3.5 \mathrm{~m}$ long butt $\log$ (from the butt end to the first live branch) was taken for the purpose of the study. It was cut into 4 central planks which were further divided into 10 sections and each section was then cut into $2 \times 2 \times 32 \mathrm{~cm}$ test specimens. All the sides of the test specimens were processed at an angle of $90^{\circ}$ to two parallel sides. Having eliminated the test specimens with defects, knots and damage, 3 completely healthy specimens with approximately parallel grain were taken from each section for the analysis.Thus we obtained a total of 120 test specimens, 60 of which were control specimens and 30 specimens were used for the fungus and for each period of incubation (2, 4 and 6 months). This number of samples is sufficient for statistical analysis, considering that 20 is considered to be the minimum number of samples (Š o š k i ć, 1994).

Before exposing them to the activity of the fungus, test specimens were measured with an accuracy of $0.01 \mathrm{~g}$, then dried to the oven dry state (in an oven at a temperature $103 \pm 1^{\circ} \mathrm{C}$ ) and measured again (all the measurements of properties were done with the oven dry wood), Immediately upon drying to the oven dry state, the control test specimens had $2 \times 2 \times 4 \mathrm{~cm}$ test specimens cut from their both ends and they were used for the measurements of the compressive strength parallel to the grain (JUS D.A1.045 and JUS D. A1. O58 (1971). All the other test specimens were dried using the standard method of drying and then conditioned to approximately $12 \%$ moisture content. The optimum moisture content for the attack of Coniophora puteana is 50-60\% (Josifović, 1951). Therefore, we put 3 petri dishes with $5 \%$ aqueous solution of boric acid in sterilized containers and thus increased the relative air humidity in the containers. The ends of the samples were sealed with an antiseptic toothpaste to prevent penetration of the fungus hyphae from that direction. We applied $0.09 \mathrm{~g}$ (dry weight) of the paste to each end surface of the test specimens. The test specimens were UV sterilized before the experiment.

The test specimens were exposed to the fungal activity by the method proposed by Mirić, M. (pers. com.). Plastic containers with lids, measuring 9 x 22 x $35 \mathrm{~cm}$ were used in the experiment. They were also sterilized using UV light. Each container had 10 plastic petri dishes arranged in two rows. They contained fullydeveloped mycelia of the tested fungus on the standard medium of malt agar. Petri dishes also acted as carriers that prevented the test specimens from coming into the direct contact with the substrate and absorbing moisture. A total of 10 sessile oak test specimens were put in each container, i.e. 5 test specimens in each row, thus there was a row of 5 petri dishes with mycelia below each of them. At the top of 
the stack, we placed Petri dishes with a 5\% aqueous solution of boric acid in order to maintain the relative air humidity. The containers were kept in a closed sterile chamber in complete darkness and the temperature was measured using a thermograph for the entire duration of the experiment. The temperature recorded in the chamber during the experiment was mostly around $20^{\circ} \mathrm{C}$, with shorter intervals of around $28^{\circ} \mathrm{C}$, which is about the optimum temperature for the growth of the investigated fungus species. After the appropriate incubation time, the test specimens were removed from the containers, cleaned of surface mycelia and dried in a classic oven at a temperature $103 \pm 1^{0} \mathrm{C}$.

In order to determine the difference between the mass of healthy wood and the wood that had been exposed to the activity of the fungus for 2, 4 and 6 months, the test specimens were measured in the oven dry state before and after the activity of the fungus, with an accuracy of $0.01 \mathrm{~g}$. The dry weight of wood before and after the activity of the fungus was used to determine the percent wood mass loss by the formula:

$$
\mathrm{Gm}=\frac{\mathrm{m}_{1}-\mathrm{m}_{2}}{\mathrm{~m}_{1}} \times 100 \%
$$

wherein:

$\mathrm{G}_{\mathrm{m}}$ - wood mass loss (\%)

$\mathrm{m}_{1}$ - mass of oven dry wood before it was exposed to the fungus $(\mathrm{g})$

$\mathrm{m}_{2}$ - mass of oven dry wood after it was exposed to the fungus $(\mathrm{g})$

Compressive strength was calculated as the maximum stress produced in the wood of a particular cross section under the pushing force applied to change the original shape by compression (Šo šk i ć, 1994). Since the compressive strength was measured on the cross-section of the test specimens, we first measured the cross diameter of the $2 \times 2 \times 4 \mathrm{~cm}$ test specimens using a micrometer with an accuracy of $0.01 \mathrm{~mm}$. It was measured using 120/291 Amsler testing machine with mechanical transmission and the speed of pusher movement amounting to 4 $\mathrm{mm} / \mathrm{min}$. The maximum tension (breakage) of the test specimens was achieved in approximately $2 \mathrm{~min}$. Compressive strength was calculated using the formula:

$$
\sigma_{\mathrm{p}}=\frac{\mathrm{F}}{\mathrm{A}}\left[\mathrm{N} / \mathrm{mm}^{2}\right]
$$

wherein:

$\sigma_{\mathrm{p}}$ - compressive strength parallel to grain $\left(\mathrm{N} / \mathrm{mm}^{2}\right)$

A - cross-sectional area of the test specimen $\left(\mathrm{mm}^{2}\right)$

$\mathrm{F}$ - maximum force $(\mathrm{N})$

\section{RESULTS AND DISCUSSION}

\subsection{Loss of Wood Mass}

Samples of $Q$. petraea agg. wood that were exposed to $C$. puteana show a significant dispersion of data in all three study periods (2, 4, and 6 months) as shown in Table 1. 
Table 1. Mass loss (\%) of Q. petraea agg. wood affected by C. puteana depending on the incubation time (basic parameters)

\begin{tabular}{|l||c|c|c|c||}
\hline & 0 mon. & 2 mon. & 4 mon. & 6 mon. \\
\hline \hline Number of measurements & 30 & 30 & 30 & 30 \\
\hline Minimum amount & 0.0 & 0.60 & 0.86 & 1.06 \\
\hline Maximum amount & 0.0 & 4.81 & 5.43 & 9.28 \\
\hline Arithmetic mean & $\mathbf{0 . 0}$ & $\mathbf{1 . 5 0}$ & $\mathbf{2 . 1 2}$ & $\mathbf{2 . 2 3}$ \\
\hline Standard deviation & 0.0 & 0.85 & 1.60 & 1.74 \\
\hline Coefficient of variation & 0.0 & 56.35 & 75.86 & 78.14 \\
\hline
\end{tabular}

Mass loss ranged from 0.60 to $4.81 \%$ in the first 2 months, from 0.86 to $5.43 \%$ after 4 months and from 1.06 to $9.28 \%$ in the last study period (6 months). The coefficient of variation was 56.35 for 2 months, 75.86 for 4 months and 78.14 for 6 months, which means that data dispersion increased with the length of $C$. puteana incubation.

The average mass loss caused by $C$. puteana was the greatest in the first 2 months and amounted to $1.50 \%$, and then almost stagnated amounting only to $2.12 \%$ after 4 months and $2.23 \%$ after 6 months. After the initial intense degradation of wood of $1.50 \%$ in the first 2 months, the differences in the mass loss decreased, so that the difference in the mass loss between the period of 2 and 4 months was $0.62 \%$ and between 4 and 6 months only $0.11 \%$. In other words, the total mass loss between the periods of 2 and 6 months was only $0.73 \%$, which was less than half the loss in the first two months. This means that the early decomposition of wood by $C$. puteana (in the first 2 months) was very intense, which is reflected in the mass loss, while it was much slower in the subsequent period (between 2 and 6 months). For this reason, future investigations should cover a longer period of time and thus study the further rate of destruction.

The results of the least significant difference test (T-test) are shown in Table 2. They are expressed in absolute amounts because relative amounts (\%) are not suitable for statistical analysis.

Table 2. Mass loss of $Q$. petraea agg. wood affected by $C$. puteana depending on the incubation time - T-test results (difference +/-)

\begin{tabular}{||l||c|c|c|c|}
\hline & 0 month & 2 month & 4 month & 6 month \\
\hline \hline 0 month & $\mathrm{x}$ & -1.32667 & -1.87800 & -1.91100 \\
\hline 2 month & & $\mathrm{x}$ & -0.55133 & -0.58433 \\
\hline 4 month & & & $\mathrm{x}$ & -0.03300 \\
\hline 6 month & & & & $\mathrm{x}$ \\
\hline
\end{tabular}

- significant difference at 0.05

The results of T-test show that there are significant differences between all the investigated groups of samples, except between 2 and 4months and between 4 and 6 months of the C. puteana incubation. It can be also seen from the data presented in the tables that these chance differences are the result of slower and uneven destruction of wood in the period between 2 and 6 months. 
Graph 1 shows the mass loss of the samples of $Q$. petraea agg. wood that were exposed to $C$. puteana for 2, 4 and 6 months compared to the control wood (wood that was not exposed to the action of the fungus).

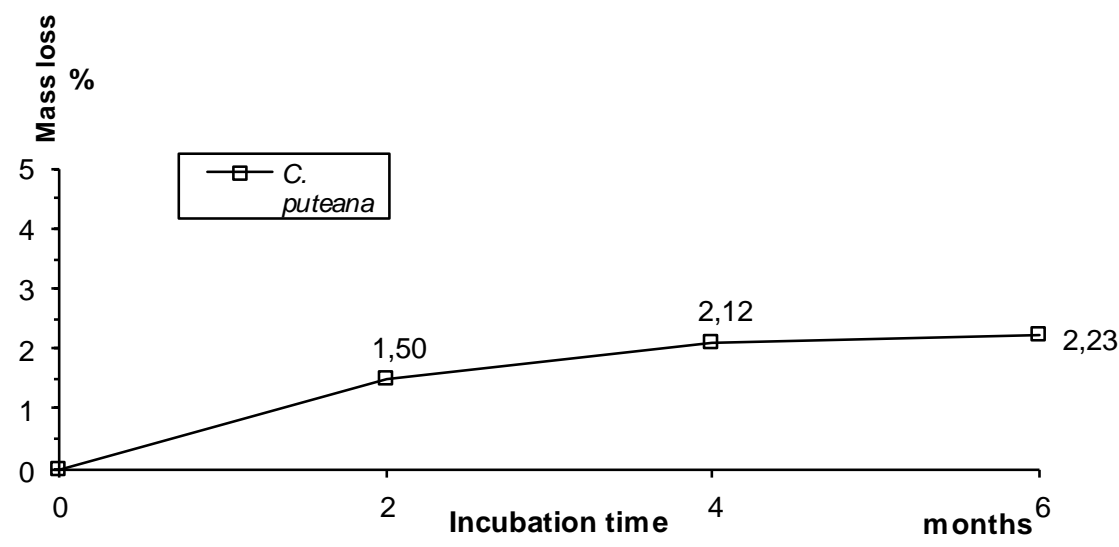

Graph 1. Wood mass loss (\%) of Q. petraea agg. caused by C. puteana depending on the incubation time

To sum up, the destruction of $Q$. petraea agg. wood affected by $C$. puteana, which was manifested in the loss of wood mass, was the most intense in the first two months after which it slowed down (between 2 and 6 months).

\subsection{Reduction of compressive strength parallel to the grain}

According to data provided by Š o šk i ć (1994), the compressive strength of healthy sessile oak wood parallel to the grain and with the standard moisture content of $12 \%$ amounts to a minimum of 48.0 , an average of 650 and a maximum of $70.0 \mathrm{~N} / \mathrm{mm}^{2}$. The author states that compressive strength decreases by $4 \%$ per one percent increase in the moisture content and vice versa, the lower the moisture in the wood, the higher the compressive strength. According to the results shown in Table 3, the compressive strength of the oven dry Q. petraea agg. wood which was not exposed to the activity of the fungus amounted to the minimum of 75.77 , an average of 93.22 and a maximum of $108.92 \mathrm{~N} / \mathrm{mm}^{2}$.

Table 3. Reduction in the compressive strength of $Q$. petraea agg. wood $\left(\mathrm{N} / \mathrm{mm}^{2}\right)$ affected by C. puteana (basic parameters)

\begin{tabular}{|l|c|c|c|c|}
\hline & 0 month & 2 month & 4 month & 6 month \\
\hline \hline Number of measurements & 30 & 29 & 28 & 26 \\
\hline Minimum amount & 75.77 & 57.18 & 62.34 & 41.50 \\
\hline Maximum amount & 108.92 & 114.47 & 115.52 & 96.62 \\
\hline Arithmetic mean & $\mathbf{9 3 . 2 2}$ & $\mathbf{9 2 . 1 3}$ & $\mathbf{9 0 . 7 2}$ & $\mathbf{7 6 . 2 5}$ \\
\hline Standard deviation & 10.51 & 15.31 & 12.03 & 14.74 \\
\hline Coefficient of variation & 11.28 & 16.61 & 13.26 & 19.32 \\
\hline
\end{tabular}

The results presented in Table 3 show that the compressive strength in the control group of samples averaged 93.22. It was 92.13 after 2 months of $C$. puteana 
activity, 90.72 after 4 months and $76.25 \mathrm{~N} / \mathrm{mm}^{2}$ after 6 months when the more intensive destruction occurred.

All the groups of samples expressed similar variability of data, with slightly higher variation after 2 and 6 months of $C$. puteana activity (coefficient of variation was 16.61 and 19.32 respectively).

The greatest reduction in compressive strength within the investigated incubation periods occurred in the period between 4 and 6 months - the difference was $15.52 \%$, which was almost 6 times greater than in the first 4 months. This does not mean that the decrease in the compressive strength was dramatic in the period between 4 and 6 months. It rather means it was insignificantly small in the first 4 months, i.e. the process of destruction was very slow in this period. This was further confirmed by the results of T-test (Table 4). Significant differences were found only for the group of samples after 6 months of fungal activity (control and 6 months, 2 and 6 months, 4 and 6 months).

Table 4. Reduction in the compressive strength of Q. petraea agg. wood $\left(\mathrm{N} / \mathrm{mm}^{2}\right)$ affected by $C$. puteana depending on the incubation time, T-test results (difference +/-)

\begin{tabular}{||l||c|c|c|c||}
\hline & 0 month & 2 month & 4 month & 6 month \\
\hline \hline 0 month & $\mathrm{x}$ & 1.09258 & 2.50417 & 16.9757 \\
\hline 2 month & & $\mathrm{x}$ & 1.41159 & 15.8831 \\
\hline 4 month & & & $\mathrm{x}$ & 14.4715 \\
\hline 6 month & & & & $\mathrm{x}$ \\
\hline
\end{tabular}

$\square$ - significant difference at 0.05

It can be said that a significant reduction in the compressive strength of $Q$. petraea agg. wood affected by $C$. puteana occurred between 4 and 6 months of fungal activity.

Graph 2 shows the reduction in the compressive strength of $Q$. petraea agg. wood affected by $C$. puteana expressed as a percentage of the control which was designated as $100 \%$ - no change in the strength (wood that was not exposed to fungal activity).

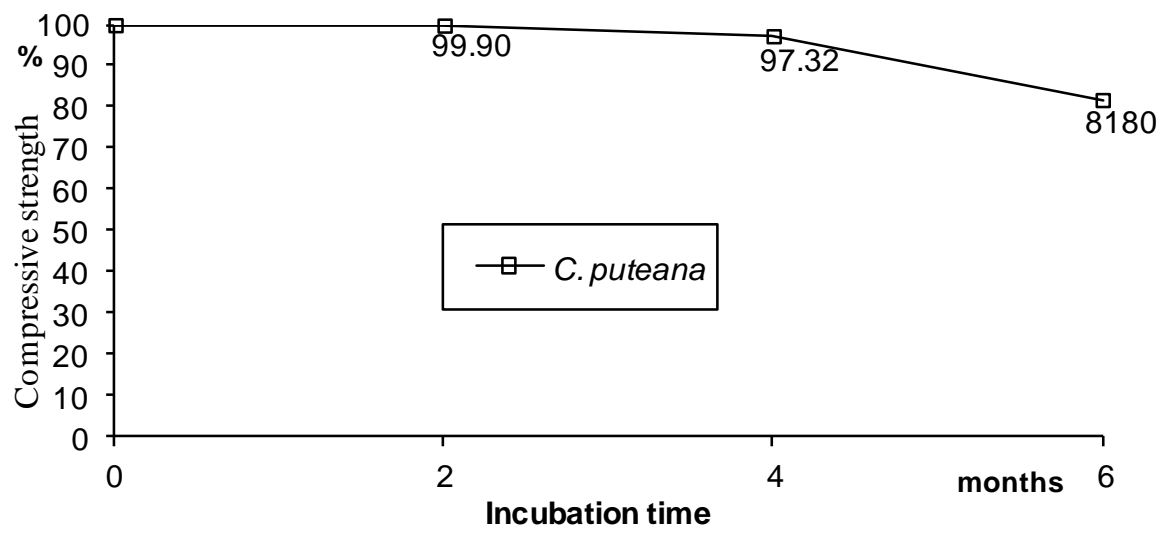

Graph 2. Reduction in the compressive strength of Q. petraea agg. wood $\left(\mathrm{N} / \mathrm{mm}^{2}\right)$ affected by $C$. puteana depending on the incubation time 
Graph 2 shows that the reduction in the compressive strength caused by $C$. puteana is negligible in the first 4 months. In the period between 4 and 6 months of the incubation, the reduction in the compressive strength is more rapid.

Table 5 shows the loss in the investigated mechanical properties of wood in relation to the mass loss after 2, 4 and 6 months of incubation. The loss in the mechanical properties is presented as the difference from the control (100\%).

Table 5. Difference in the loss of mechanical properties (\%) of Q. petraea agg.wood affected by C. puteana

\begin{tabular}{|c|c|c|c|}
\hline \multirow{2}{*}{ Wood property } & \multicolumn{3}{|c|}{ Incubation of C. puteana } \\
\cline { 2 - 4 } & 2 month & 4 month & 6 month \\
\hline Mass loss & 1.50 & 2.12 & 2.23 \\
\hline Compressive strength & 0.10 & 2.68 & 18.20 \\
\hline
\end{tabular}

The table shows the percent decrease in the investigated mechanical property relative to the mass loss, after a period of incubation, which is important in the practical application of the research results.

For the purpose of determining the correlation between the investigated properties of $Q$. petraea agg. and the incubation time, we conducted a correlation analysis (Table 6).

Table 6. Overview of data of the correlation analysis of the incubation time of $C$. puteana and investigated properties of $Q$. petraea agg.wood

\begin{tabular}{||c|c|c|c||}
\hline \hline Investigated property & Model type & $\begin{array}{c}\text { Coefficient of } \\
\text { correlation } \\
(\mathrm{r})\end{array}$ & Regression equation \\
\hline \hline $\begin{array}{c}\text { Mass loss } \\
\left(\mathrm{G}_{\mathrm{m}}\right)\end{array}$ & $\begin{array}{c}\text { The quadratic } \\
\text { function }(\mathrm{x})\end{array}$ & 0.990032 & $\mathrm{G}_{\mathrm{m}}=0.0638492+0.954107 \times \sqrt{\mathrm{T}}$ \\
\hline $\begin{array}{c}\text { Compressive strength } \\
\left(\sigma_{\mathrm{p}}\right)\end{array}$ & Linear model & -0.84605 & $\sigma_{\mathrm{p}}=96.328-2.666 \times \mathrm{T}$ \\
\hline
\end{tabular}

The correlation analysis of the changes in the mechanical and physical properties of $Q$. petraea agg. wood in relation to the time of $C$. puteana incubation shows a strong correlation between the variables. The presented regression equations open the possibility of forecasting changes in the properties of wood in certain periods of fungal activity under the same environmental conditions. These findings can have important practical benefits in taking measures of protection and increasing the usability of wood.

\section{CONCLUSIONS}

The samples of $Q$. petraea agg. wood were used to test the effects of $C$. puteana on the mass loss and compressive strength parallel to the grain in the incubation periods of 2, 4 and 6 months. The performed investigations produced the following conclusions:

The mass loss of $Q$. petraea agg. wood affected by $C$. puteana after 2, 4 and 6 months of incubation was $1.50 \%, 2.12 \%$ and $2.23 \%$ respectively, which means that the greatest mass loss of the wood affected by $C$. puteana occurred in the first two months. 
Compressive strength of $Q$. petraea agg. wood affected by $C$. puteana decreased after 2, 4 and 6 months of incubation and amounted to $99.90 \%, 97.32 \%$ and $81.80 \%$, compared to the control $(100 \%)$. This means that the greatest reduction in compressive strength of the wood affected by $C$. puteana occurred in the period between 4 and 6 months.

Correlation analysis pointed to a strong correlation between the properties of $Q$. petraea agg. wood and the time of incubation. These findings have opened up the possibility of forecasting changes in the properties of wood in certain periods of fungal activity under the same environmental conditions. The obtained regression equations can be used to determine the reduction of mechanical properties of wood in a given period of fungal activity.

Future studies should include similar experiments performed with the most important wood species in our country and the most dangerous wood destructors, but with a greater number of monitoring periods, which would form a solid basis for the development of adequate tables (standards). Bearing in mind the woodfungus interaction and the impact of the environment, if we want the results to have broader application (in areas with different climates), parallel experiments should be set up with the isolates of a fungus and the samples of a tree species from different geographical areas (the ones in which the fungus most frequently occurs and which are within the area of distribution of the investigated tree species). A comparative analysis of the obtained data and their statistical processing would provide the most accurate data that could be classified in the appropriate tables and applied in practice.

\section{REFERENCES}

Čeremesinov, N.A., Negruckij, S.F., Leškovceva, I.I. (1970: Gribi i gribnie bolezni derevjev i kustarnikov, Lesnaja promišlenost, Moscow

Josifović, M. (1951): Forest Phytopathology, Scientific Book, Belgrade

Mirić, M., Popović, Z. (1993): The effect of Pleurotus ostreatus (Jacq.) Fr. and Trametes versicolor (L. ex Fr.) Pilat on the loss of hardness, compressive strength and mass of beech wood, Lumber Bullettin, no. 6-7, Belgrade, 36-40

Muntañola-Cvetković, M. (1987): General mycology, NIRO Književne novine, Belgrade

Petrović, M. (1980): Protection of wood 2, Scientific Book, Belgrade

Rypáček, V. (1957): Biologie drevokaznych hub, Nakladestivi československe Akademie Ved, Praha

Tomic, Z. (1992): Forests phytocenoses of Serbia, Faculty of Forestry, Belgrade, 26

Šoškić, B. (1994): Properties of wood, Faculty of Forestry, University of Belgrade, Belgrade

Uščuplić, M. (1996): Pathology of forest and ornamental trees, Faculty of Forestry, University of Sarajevo, Sarajevo, 297 
JUS D. A1. O58 (1971): Examination of the resistance to fungi, Moscow

\title{
EFFECTS OF Coniophora puteana (Schumach.) P. Karst. FUNGUS ON THE DECOMPOSITION OF SESSILE OAK WOOD
}

\author{
Miroslava MARKOVIĆ, Snežana RAJKOVIĆ
}

\section{Summary}

The test samples were taken from the heartwood of a healthy Quercus petraea agg. tree from Quercetum montanum (Čer. et Jov., 1953) association. The wood samples were exposed to the mycelia of the fungus that causes brown cubical rot of oak wood Coniophora puteana (Schumm. ex Fr.) Karst. (cellar fungus) for 2, 4 and 6 months. It was performed according to the method proposed by Mirić, M. (pers.com.). In order to assess the impact of $C$. puteana on the reduction in the properties of $Q$. petraea agg. wood, we investigated the mass loss of wood and the compressive strength parallel to the grain. It was found that the mass loss of $Q$. petraea agg wood after 2, 4 and 6 months of Coniophora puteana incubation amounted to $1.50 \%, 2.12 \%$ and $2.23 \%$ respectively. The compressive strength parallel to the grain of $Q$. petraea agg. wood affected by $C$. puteana decreased to $99.90 \%, 97.32 \%$ and $81.80 \%$. Besides the individual loss values of the stated properties of wood, the paper presents a comparative overview of the correlation between the decrease in the mechanical properties and the mass loss, depending on the time of $C$. puteana incubation, on the basis of which we determined the percent reduction in the compressive strength of $Q$. petraea agg. wood for the determined mass loss values after 2, 4 and 6 months. In the conclusions, we stressed that the future studies should include similar experiments performed with the most important wood species in our country and the most dangerous wood destructors, but with a greater number of monitoring periods, which would form a solid basis for the development of adequate tables (standards). Bearing in mind the fungus-wood interaction and the impact of the environment, the obtained results could have broader application (in areas with different climates) and parallel experiments could be set up with the isolates of a fungus and the samples of a tree species from different geographical areas (the ones in which the fungus most frequently occurs and which are within the area of distribution of the investigated tree species). A comparative analysis of the obtained data and their statistical processing would provide the most accurate data that could be classified in the appropriate tables and applied in practice.

\section{DEJSTVO GLJIVE Coniophora puteana (Schumach.) P. Karst. NA RAZLAGANJE DRVETA HRASTA KITNJAKA}

\author{
Miroslava MARKOVIĆ, Snežana RAJKOVIĆ
}

\section{Rezime}

Uzorci za ispitivanja uzeti su iz srčike zdravog stabla Quercus petraea agg., iz asocojacije Quercetum montanum (Čer. et Jov., 1953). Uzorci drveta su 2, 4 i 6 meseci izlagani dejstvu micelije gljive koja izaziva mrku prizmatičnu trulež hrastovog drveta Coniophora puteana (Schumm. ex Fr.) Karst. (podrumska gljiva), po metodu koji je predložio Mirić, M. 
(pers.com.). U cilju utvrđivanja uticaja vrste $C$. puteana na smanjenje svojstava drveta $Q$. petraea agg., ispitivan je gubitak mase drveta, i čvrstoće na pritisak paralelno sa vlakancima. Utvrđeno je da je gubitak mase drveta $Q$. petraea agg. pod dejstvom gljive $C$. puteana posle 2, 4 i 6 meseci iznosi 1,50\%, 2,12\% i 2,23\%. Čvrstoća na pritisak paralelno sa vlakancima, drveta $Q$. petraea agg. pod dejstvom gljive $C$. puteana smanjila se na $99,90 \%, 97,32 \%$ i $81,80 \%$. U radu je pored pojedinačnih prikaza gubitka pomenutih svojstava drveta, dat i uporedni prikaz gubitka mehaničkih svojstava u odnosu na gubitak mase, zavisno od vremena dejstva gljive C. puteana, na osnovu koga je za utvrđene gubitke mase određen procenat smanjenja čvrstoće na pritisak drveta $Q$. petraea agg. posle 2, 4 i 6 meseci. U zaključnim razmatranjima konstatovano je da bi u budućim istraživanjima trebalo slične oglede trebalo sprovesti sa našim najvažnijim vrstama drveta i najznačajnijim i najopasnijim destruktorima drveta, sa većim brojem perioda praćenja, na osnovu kojih bi se mogle formirati odgovarajuće tablice (standardi). Imajući u vidu interakciju gljiva - drvo i niz uticaja spoljne sredine, ovako dobijeni rezultati bi imali širu primenu (u različitim klimatskim područjima), a postoji i mogućnost paralelnog postavljanja ogleda sa izolatima jedne gljive i uzorcima jedne vrste drveta, ali sa različitih geografskih područja (i to onih u kojima se gljiva najčešće javlja, a koja pripadaju arealu te vrste drveta). Ukrštanjem dobijenih podataka i njihovom statističkom obradom, dobile bi se najpribližnije vrednosti koje bi se mogle svrstati u odgovarajuće tablice i praktično primenjivati. 